RESEARCH ARTICLE

\title{
Understanding the Dormancy Trait in Subabul (Leucaena leucocephala Lam.) as Influenced by Seed Coat Color Intensities
}

\section{Tamilarasan C*, Jerlin R and Raja K}

*Department of Seed Science and Technology, Tamil Nadu Agricultural University, Coimbatore - 641003.

Received : $10^{\text {th }}$ February, 2020

Revised : $22^{\text {nd }}$ February, 2020

Revised : $12^{\text {th }}$ March, 2020

Accepted : $25^{\text {th }}$ March, 2020

\begin{abstract}
Subabul (Leucaena leucocephala Lam.) is a fast-growing perennial, nonclimbing fodder tree with an excellent source of protein. Its seed has physical dormancy (hard seed coat) that prevents the entry of water molecules into a seed, which leads to poor germination. In the present study, the fresh seeds were collected and observed for morphological characters viz., seed color, size, shape, 100 seed weight, and germination. Seed color, size, and germination test were analyzed under shade net condition. The results showed significant differences in both light and dark brown colored seeds. Light brown colored seeds recorded higher germination (88\%) with lower dormancy and vice versa in the case of dark brown seeds where the germination was $31 \%$. From this study, it is concluded that the seed coat color intensity influences the dormancy level of leucaena seeds. Hence, the light brown seeds do not require any preconditioning whereas, dark brown colored seeds need pre-germination dormancy breaking to improve the germination of seeds.
\end{abstract}

Keywords: Subabul, Leucaena leucocephala, seed coat color, seed size, seed shape, depth of physical dormancy.

\section{INTRODUCTION}

Subabul (Leucaena leucocephala Lam.) is a perennial non-climbing, non-spiny shrub or tree which is originated from Tropical America. This is commonly referred to as a white lead tree, jumbay, subabul and white popinac. Since it is a tropical species, it requires an optimum temperature of 25 to $30^{\circ} \mathrm{C}$ for its growth. It is an arboreal legume that has the ability to fix the atmospheric nitrogen through the symbiotic association with the Rhizobium. It is a small tree reaching up to the height of 3-15 m tall with bipinnate leaves. Flowers are arranged in the compact globose head with 100-180 flowers per head. Pods are 9-19 cm long with papery pod walls, which results in prolific seed production of 8 to 30 seeds per pod. Seeds are oval, flattish, and brown, 6.7-9.6 mm long, and 4-6.3 mm wide. Due to its multipurpose usages like fodder and timber, it is referred to as "alfalfa of the tropics.

Even though this species possess several valuable characteristics, seeds fail to germinate due to the presence of dormancy. Generally, seed dormancy can be imposed by the embryo, the envelopes (seed coat), or a combination of both factors to the extent that depends on the plant species (Bewley, 1997). In subabul, the presence of a hard seed coat is responsible for poor seed germination, which is considered as physical dormancy. Physical dormancy is caused due to the presence of water-impermeable palisade layers in the seed coat, which prevent the imbibition of water. The hard seed coat is responsible for resistance to a favourable environmental condition resulting in delayed and poor seed germination (Lavania et al., 2018).

In general, dormant seeds are identified by subjecting the seeds to the condition which prevent the initiation of metabolic processes and embryo growth. However, the dormant seeds can also be identified through external characteristics like seed color, shape, and size. According to Duran and Retamal (1989), red seeds of charlock (Sinapis arvensis) exhibit a reduced dormancy compared with black seeds. In wheat, the strongest dormancy is associated with a red seed coat color, whereas the seeds with white seed coat are non-dormant or weakly dormant (Gfeller and Svejda, 1960; Mares, 1994). There are several works related to the presence of physical dormancy in the subabul and its overcoming strategies. However, scarce information is available related to the seed color, size, and shape on the degree of dormancy. Therefore, the present study was conducted to identify the degree of seed dormancy through the seed color, shape, and size in subabul. 


\section{MATERIAL AND METHODS}

The study was conducted at the Department of Seed Science and Technology, Tamil Nadu Agricultural University, Coimbatore, during 2019. Subabul seeds of light and dark brown genotypes were collected from the Department of Forage Crops, Tamil Nadu Agricultural University, Coimbatore. Morphological characters viz., seed color, size, shape, and 100 seed weight were recorded. Therefore, the seeds were subjected to germination test as per ISTA (2015).

\section{Seed color}

Fresh seeds were examined both visually and by stereo zoom microscope for differentiating the color of seed coats. The surface of the seed coats were observed closely to identify the color intensity. Light and dark brown colored seeds were observed.

\section{Seed size}

Randomly selected seeds from both light and dark brown color varieties were evaluated for seed size viz., length, width, and thickness using Vernier caliper meter. Measured parameters are expressed in $\mathrm{mm}$.

\section{0 seed weight}

A hundred seeds from both light and dark brown colored seeds were randomly counted in four replications weighed and expressed in gram.

\section{Imbibition rate}

Light and dark brown colored seeds were tested for imbibition rate, 150 seeds from each colored seeds were taken and soaked in 1:1 ratio of water and seed ( $\mathrm{v} / \mathrm{v}$ ). At periodical intervals (one hour), soaked seeds were taken surface water was removed, and the seed weight was measured.

\section{Speed of germination (Maguire, 1962)}

The germinated seedlings from each replication of treatments were counted daily from $1^{\text {st }}$ day onwards up to $10^{\text {th }}$ day of sowing. From the number of seeds germinated on each day, the speed of germination was calculated using the following formula, and the result was expressed in number. Where,

X1- Number of seeds germinated at first count

X2- Number of seeds germinated at second count

$\mathrm{Xn}$ - Per cent germination on nth day

Y1- Number of days from sowing to first count

Y2- Number of days from sowing to second count

$\mathrm{Yn}$ - Number of days from sowing to nth count

\section{Germination test}

Germination test were conducted under shade net condition with raised bed. At the end of 30 days the number of normal seedlings were recorded for calculating germination per cent. Also, dormancy per cent was calculated by counting the number of hard seeds present at the final count day of the germination test ISTA (2015).

$$
\begin{aligned}
& \text { Germination }(\%)=\frac{\text { No. of Normal needlings }}{\text { Total no. of seeds sown }} \times 100 \\
& \text { Dormancy }(\%)=\frac{\text { No. of hard seeds }}{\text { Total no. of seeds sown }} \times 100
\end{aligned}
$$

The data collected were subjected for the analysis of variance, and comparison was made by Duncan's Multiple Range Test (DMRT). The significant differences were noted at the P-values $<0.05$. Statistical analysis was performed using the SPSS 16.0 software (SPSS Inc., Chicago, USA).

\section{RESULT AND DISCUSSION}

Results revealed that significant differences were observed in morphological characters viz., seed coat color, seed size, length, breadth, thickness, shape, and 100 seed weight.

Seed color differences in subabul were conformed with the Royal Horticultural Society Color Chart, in

\begin{tabular}{|c|c|c|c|c|c|}
\hline \multirow{2}{*}{ Seed color } & \multicolumn{3}{|c|}{ Seed size } & \multirow{2}{*}{ Seed shape } & \multirow{2}{*}{$\begin{array}{l}100 \text { seed } \\
\text { weight (g) }\end{array}$} \\
\hline & Length (mm) & Width (mm) & Thickness (mm) & & \\
\hline Light brown & $8.650 .03^{a}$ & $5.540 .05^{a}$ & $1.610 .01^{\mathrm{a}}$ & Ovoid wide & $5.750 .09^{a}$ \\
\hline Dark brown & $7.060 .09^{b}$ & $4.340 .04^{b}$ & $1.370 .02^{b}$ & Ovoid elongated & $5.150 .06^{b}$ \\
\hline
\end{tabular}

Table 1. Physical Characters of light and dark color Leucaena leucocephala seeds

which light-colored seeds (Brown group, 200-D) and dark colored seeds (Brown group, 200-B) were noticed. The seed length $(8.65 \mathrm{~mm})$, breadth $(5.54$ $\mathrm{mm})$, thickness $(1.61 \mathrm{~mm})$ were more in light colored seeds, whereas, minimum seed length $(7.06 \mathrm{~mm})$, breadth (4.34 mm), and thickness $(1.37 \mathrm{~mm}$ ) were recorded in dark colored seeds. Seed shape also differing from each other in which light-colored seed was ovoid wide, and dark colored seed was ovoid elongated (Figure 1). Variations in 100 seed weight were noticed in which light-colored seeds have recorded higher weight (5.75 g) than dark colored seeds (5.15 g) (Table 1).

Further, the colored seeds were subjected for imbibition test with 150 seeds from each color. Out of 150 seeds, around 126 seeds were imbibed, which was $84 \%$ in light colored seeds, while only 

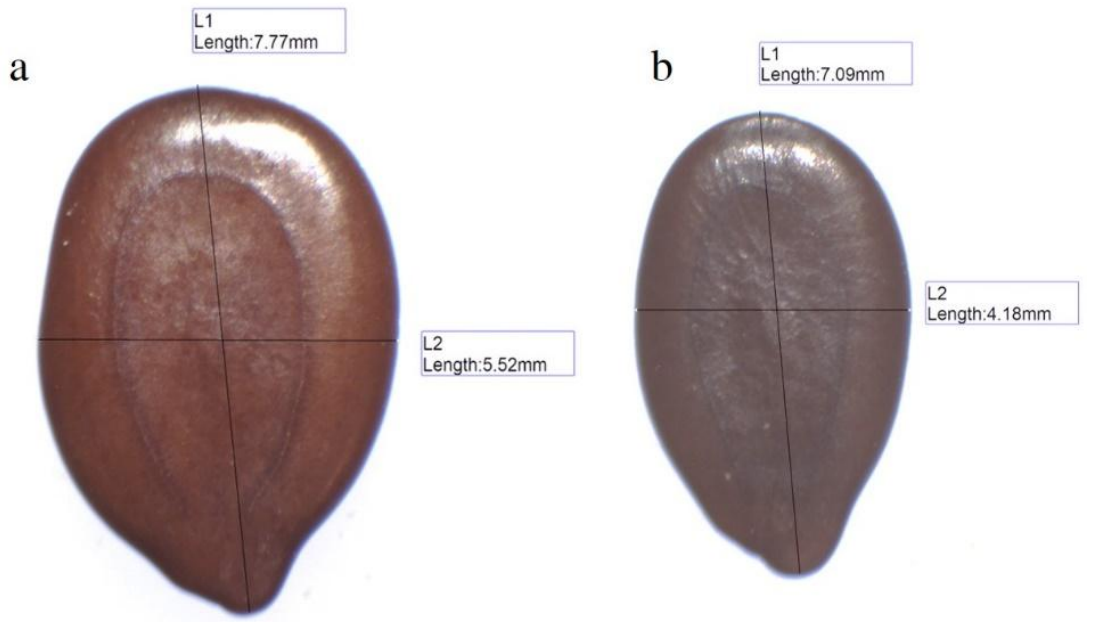

Figure 1. Physical characters of light and dark colored seeds of subabul

a). Light colored seed, b). Dark colored seed

11 seeds were imbibed, which was $7 \%$ (Figure 2). It indicated seed coat color influences the depth of physical dormancy. In the germination test, the maximum number of light colored seeds were emerged earlier, i.e., within 15 days after sowing, when compared to dark colored seeds. The highest speed of emergence (16.2) was recorded in light colored seeds, than the dark seeds (7.8). Also, the

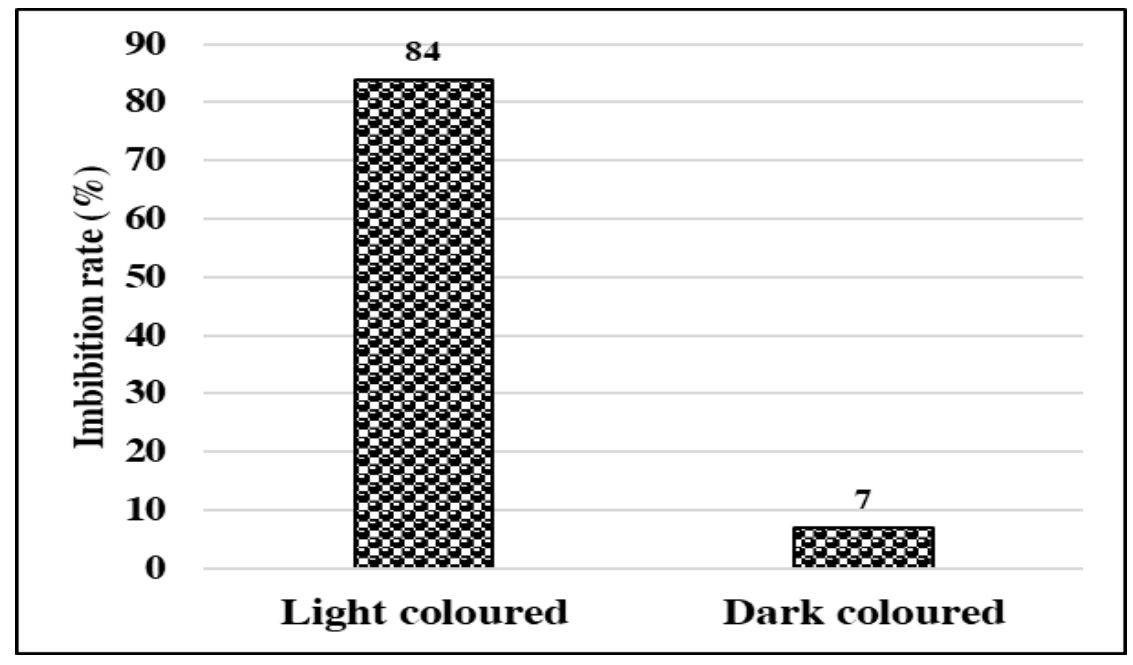

Figure 2. Imbibition rate (\%) of light and dark colored subabul seeds

highest germination (88\%) was observed in light colored seeds, than the dark colored seeds (31\%). It revealed that about 70 per cent dormant seeds were present in dark colored seeds and only 12 per cent in light colored seeds (Table 2 and Figure 3a, b).
The tannin content at different concentrations of the seeds leads to changes in seed color. Tannin content also influences the thickness and hardness of the seed coat, which causes an impermeable seed coat to water and oxygen.

Table 2. Physical and physiological characters of light and dark color subabul seeds

\begin{tabular}{lrrrrrrr}
\hline Seed colour & $\begin{array}{r}\text { Hard seeds } \\
\text { (No's) }\end{array}$ & \multicolumn{2}{c}{ Dormancy (\%) } & $\begin{array}{r}\text { Speed of } \\
\text { emergence }\end{array}$ & Germination (\%) & Dead seeds (\%) \\
\hline Light brown & $241.11 \mathrm{a}$ & $12(20.27)$ & $1.08 \mathrm{a}$ & $16.20 .17 \mathrm{a}$ & $88(69.73)$ & $1.21 \mathrm{a}$ & 0 \\
Dark brown & $1391.99 \mathrm{~b}$ & $69(56.17)$ & $1.06 \mathrm{~b}$ & $7.80 .10 \mathrm{~b}$ & $31(33.83)$ & $1.55 \mathrm{~b}$ & 0 \\
\hline
\end{tabular}

(Figures in parenthesis indicate arcsine values). Data presented are means from ten replicates with standard errors. Within each treatment, different letters at each column indicate significant differences by Duncan's multiple range test at $\mathrm{P}<0.05$.

Hard seed coat inhibits the entry of essential requirements for seed germination, which ends in the failure of germination and seedling establishments. The physical dormancy (hard seed coat) is the major problem in most of the legume crops, which is regulated by pigments such as tannins (Penfield and MacGregor, 2017; Davies, 1975). Seeds of Acacia species show a vast range of differences in 
color, size, and shape (Escobar et al., 2010). The pigmentation of the seed coat color was primarily determined by flavonoids and anthocyanins (Dixon and Sumner, 2003). It was stated that dark seed coat color has a higher concentration of anthocyanins and proanthocyanidins than lighter colors (Ranilla et al., 2007). The hard seed coat is impervious to favorable germination conditions following the results of ZakyZayed et al. (2014). Wang et al. (2012) reported that the ratio of brown to black seeds produced by Suaeda aralocaspicavia plants that are dependent on the color of the seed coat.

\section{Light colored seeds}

Dark colored seeds
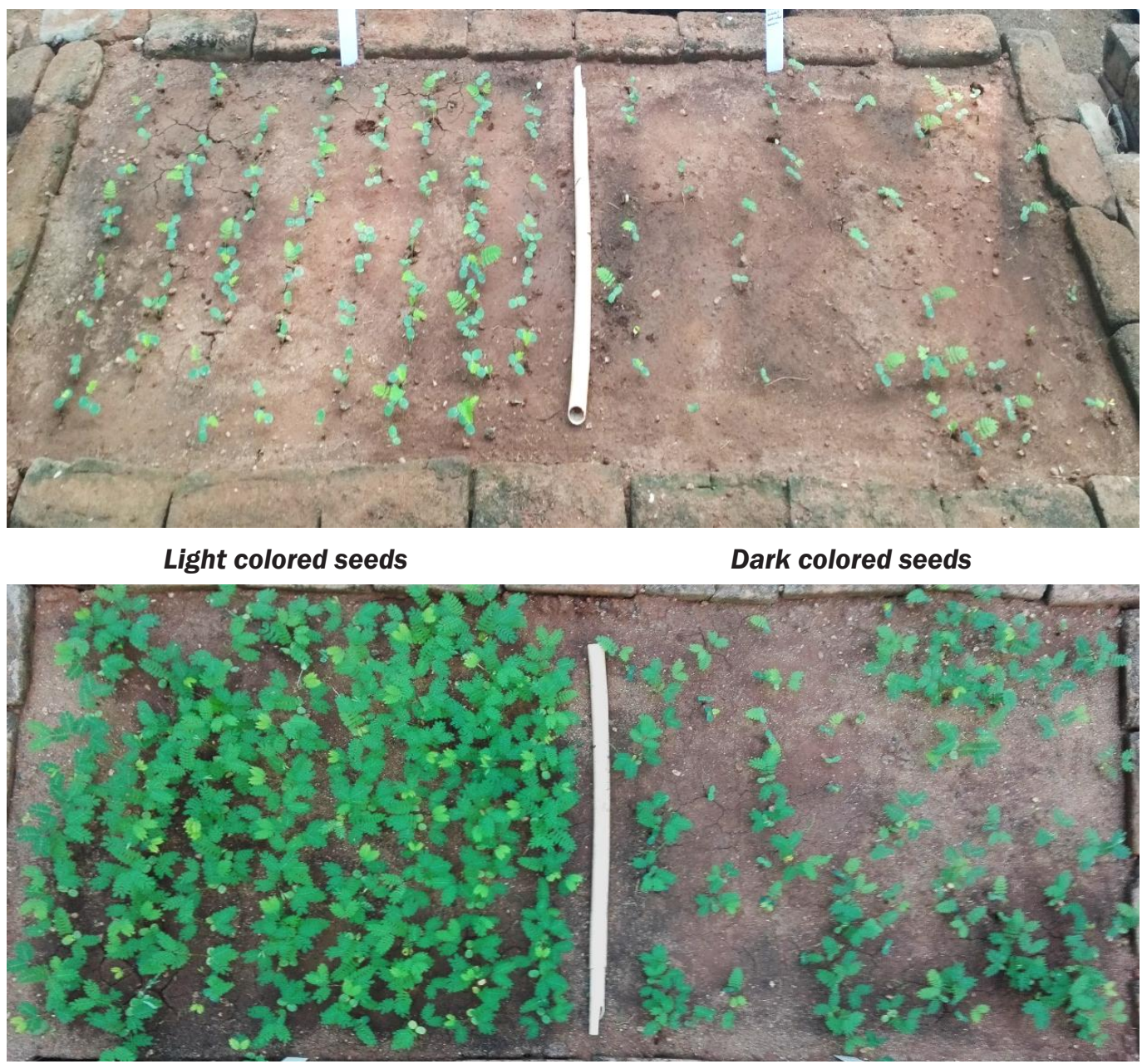

Figure 3. Effect of seed coat color on germination (\%) in subabul seeds

a). Germination of light and dark colored seeds at 15 days after sowing

b). Germination of light and dark colored seeds at 30 days after sowing

\section{CONCLUSION}

The results from the present experiment concluded that the intensity of seed coat color influences the dormancy level of subabul seeds. Hence, the light brown colored seeds do not require any preconditioning treatment, whereas, in dark colored seeds requires pre-germination treatments.

Therefore, acid scarification or mechanical scarification or rubbing with a rough surface to soften the seed coat is required for dark colored seeds to break the seed dormancy.

\section{REFERENCES}

Bewley, J. Derek. 1997. Seed germination and dormancy. The plant cell, 9(7): 1055.

Davies, D.R. 2003. Studies of seed development in Pisum sativum. Planta, 124(3): 297-302.

Dixon, R.A. and L.W. Sumner. 2003. Legume natural products: understanding and manipulating complex pathways for human and animal health. Plant Physiology, 131(3): 878-885.

Duran, J.M. and N. Retamal. 1989. Coat structure and regulation of dormancy in Sinapis arvensis L. seeds. Journal of Plant Physiology, 135(2): 218-222. 
Escobar, T.A., V. M. Pedroso, R. N. Bonow and E. B. Schwengber. 2010. Overcoming dormancy and temperatures for seed germination of Acacia caven (Mol.) Mol. Revista Brasileira de Sementes, 32(2): 124-130.

Gfeller, F. and F. Svejda. Inheritance of post-harvest seed dormancy and kernel colour in spring wheat lines. Canadian Journal of Plant Science, 40(1): 1-6.

ISTA. 2015. International Rules for Seed Testing. International Seed Testing Association, Switzerland.

Lavania, P., Tiwari, A. and N. Kumar. Studies on maturity Indicators of Leucaena leucocephala in Northern India. International Journal of Current Microbiology Applied Science, 7(12): 3636-3643.

Mares, M. 1994. Computation over fuzzy quantities. CRC press, New york.

Penfield, S. and D.R. MacGregor. 2017. Effects of environmental variation during seed production on seed dormancy and germination. Journal of Experimental Botany, 68(4): 819-825.
Ranilla, L.G., I.G. Maria and F.M. Lajolo. 2007. Polyphenols and antioxidant capacity of seed coat and cotyledon from Brazilian and Peruvian bean cultivars (Phaseolus vulgaris L.). Journal of Agricultural and Food Chemistry, 55(1): 90-98.

Wang, L., J. M. Baskin, C. C. Baskin, J. H. C. Cornelissen, M. Dong and Z. Huang. 2012. Seed dimorphism, nutrients and salinity differentially affect seed traits of the desert halophyte Suaeda aralocaspica via multiple maternal effects. BMC Plant Biology, 12(1): 170.

ZakyZayed, M.W.S.H., S.L. Pang and F.B. Ahmad. 2014. EMS-induced mutagenesis and DNA polymorphism assessment through ISSR markers in Neolamarckia cadamba (kelampayan) and Leucaena leucocephala (petai belalang). European Journal of Experimental Biology, 4(4): 156-163. 